\title{
OPSI PENGELOLAAN IKAN TEMBANG (SARDINELLA FIMBRIATA) DI PERAIRAN KABUPATEN SUBANG, JAWA BARAT
}

\author{
Titin Salmah ${ }^{1}$, Benny Osta Nababan dan Ujang Sehabuddin ${ }^{2}$ \\ ${ }^{1}$ Alumni Departemen Ekonomi Sumberdaya dan Lingkungan, FEM, IPB \\ ${ }^{2}$ Dosen pada Departemen Ekonomi Sumberdaya dan Lingkungan, FEM, IPB \\ Diterima 10 Maret 2011 - Disetujui 4 Juni 2012
}

\begin{abstract}
ABSTRAK
Penelitian bertujuan menganalisis dampak kebijakan pajak dan jadwal melaut terhadap pemanfaatan ikan tembang di perairan Kabupaten Subang telah dilakukan pada tahun 2011. Pengumpulan data dilakukan dengan purposive sampling terhadap nelayan purse seine di TPI Belanakan, hasilnya dianalisis menggunakan metode analisis model bioekonomi. Hasil penelitian menunjukkan penangkapan ikan tembang belum mengalami tangkap lebih (biological overfishing), tetapi jumlah effort yang digunakan nelayan purse seine telah mengalami overcapacity atau effort yang berlebih. Kondisi ini melandasi opsi kebijakan pengaturan hari melaut (trip) sesuai dengan jumlah trip pada kondisi sole owner (MEY) yang dikombinasikan dengan pengembangan agroindustri tepung ikan tembang sebagai kompensasi untuk menghindari peningkatan aktifitas yang kurang produktif. Penerapan kebijakan berupa penerapan pajak ini akan menjadi solusi jangka panjang untuk eksploitasi sumberdaya ikan tembang yang berlebih.
\end{abstract}

Kata kunci: model bioekonomi, ikan tembang (Sardinella fimbriata), Kabupaten Subang.

Abstract : Tembang Fish Management Option (Sardinella fimbriata) in Subang Regency, West Java. By: Titin Salmah, Benny Osta Nababan and Ujang Sehabuddin.

The study aims to analyze the impact of the tax policy and schedule to sea toward utilization of Tembang fish in Subang regency have been conducted at 2011. Data collected by purposive sampling from purse seine fisheries operate at TPI Belanakan and the result was analyzed using bioeconomic model method. The research showed that Tembang fish has not run into overexploitation (biological overfishing), but the amount of effort used by purse seine fishermen has been overcapacity or excessive effort. Suggested Policy recommendations is to conduct policy-setting day at sea (trip) in accordance with the number of trips on the condition sole owner (MEY) combined with the development agroindustry of Tembang fish flour as compensation to avoid an increasing less productive activities. The application of tax policy will be a long term solution for the exploitation of tembang fish.

Keywords : bioeconomic modelling, tembang fish (Sardinella fimbriata), Subang Regency 


\section{PENDAHULUAN}

Sumberdaya ikan yang menjadi target nelayan adalah jenis ikan yang memiliki nilai ekonomi tinggi. Pemanfaatan ikan bernilai jual tinggi di perairan Kabupaten Subang diduga telah menyebabkan terjadinya kelangkaan. Kondisi ini dirasakan oleh nelayan purse seine yang beroperasi di perairan Kabupaten Subang, di mana dalam pencarian ikan bernilai jual ekonomis tinggi didapatkan $17 \%$ dari hasil tangkapan dan sisanya adalah jenis ikan tembang (Sardinella fimbriata) yang bernilai jual rendah (Dinas Kelautan dan Perikanan Kabupaten Subang, 2008). Hal ini menunjukkan potensi ikan tembang di Perairan Kabupaten Subang tersedia cukup tinggi dan telah terjadi peralihan target pemanfaatan jenis ikan, dari jenis yang semakin langka dan bernilai jual tinggi ke jenis ikan tembang. Konsekuensinya, jika pemanfaatan ikan tembang tidak terkendali, maka akan menyebabkan kepunahan bagi sumber daya tersebut.

Perairan Subang terletak di bagian utara Provinsi Jawa Barat yang berhadapan langsung dengan Laut Jawa. Secara implisit perairan tersebut berkontribusi dalam pemanfaatan sumber daya ikan pelagis kecil di WPP Laut Jawa, terutama jenis ikan tembang. Berdasarkan data Dinas Kelautan dan Perikanan Kabupaten Subang (2008), jenis ikan yang dominan dihasilkan adalah ikan tembang. Ikan tembang merupakan jenis ikan pelagis kecil yang memiliki kandungan omega 3 tinggi, yaitu sebesar 3,90 gram per 100 gram ikan sehingga baik digunakan untuk konsumsi dan pakan. Keunggulan tersebut menunjukkan perlunya perhatian terhadap kelestarian ikan tembang. Jika pemanfaatan ikan ini tidak dikontrol dari sekarang, maka akan mengancam kelestarian atau kepunahan bagi sumberdaya ikan tembang di masa mendatang. Untuk mengontrol tingkat eksploitasi perikanan tembang di Kabupaten Subang maka perlu dilakukan analisis bioekonomi, dimana secara biologi ikan tembang dapat lestari dan secara ekonomi nelayan dapat tetap memperoleh keuntungan dari pemanfaatan ikan tembang tersebut.
Tujuan dari penelitian ini adalah :

1) menganalisis kondisi hasil tangkapan, effort dan rente ekonomi aktual ikan tembang;

2) mengestimasi jumlah tangkapan, effort dan rente ekonomi ikan tembang yang optimal secara biologi dan ekonomi;

3) menganalisis implikasi kebijakan (pajak dan pengaturan jadwal melaut yang dikombinasikan dengan agroindustri) terhadap pemanfaatan ikan tembang di Perairan Kabupaten Subang.

\section{METODE PENELITIAN}

\section{Kerangka Pemikiran}

Berdasarkan data produksi Kabupaten Subang, ikan tembang merupakan ikan yang banyak dihasilkan di Perairan Kabupaten Subang (BPS Kabupaten Subang, 2008). Ikan tembang merupakan bagian dari jenis ikan yang tergolong murah. Namun, bukan berarti ikan tersebut tidak penting untuk diperhatikan. Jika penangkapan ikan tembang tidak dikontrol dari sekarang, dikhawatirkan akan terjadi kepunahan sumber daya ikan tembang pada masa yang akan datang sehingga kebutuhannya sebagai bahan baku tidak akan terpenuhi. Oleh karena itu, diperlukan suatu regulasi dalam pemanfaatan ikan tembang, yaitu dengan menggunakan analisis bioekonomi. Keterangan ini dapat diperjelas dengan kerangka pemikiran pada Gambar 1.

\section{Lokasi dan waktu penelitian}

Penelitian dilaksanakan di Desa Blanakan, Kecamatan Blanakan, Kabupaten Subang, Propinsi Jawa Barat dengan pertimbangan bahwa TPI di desa ini merupakan pangkalan ikan yang sudah maju dan memiliki kontribusi yang tinggi dalam menghasilkan penangkapan ikan tembang di Kabupaten Subang. Penelitian ini dilaksanakan pada bulan Agustus sampai September 2009 dan Juli sampai Agustus 2010. 


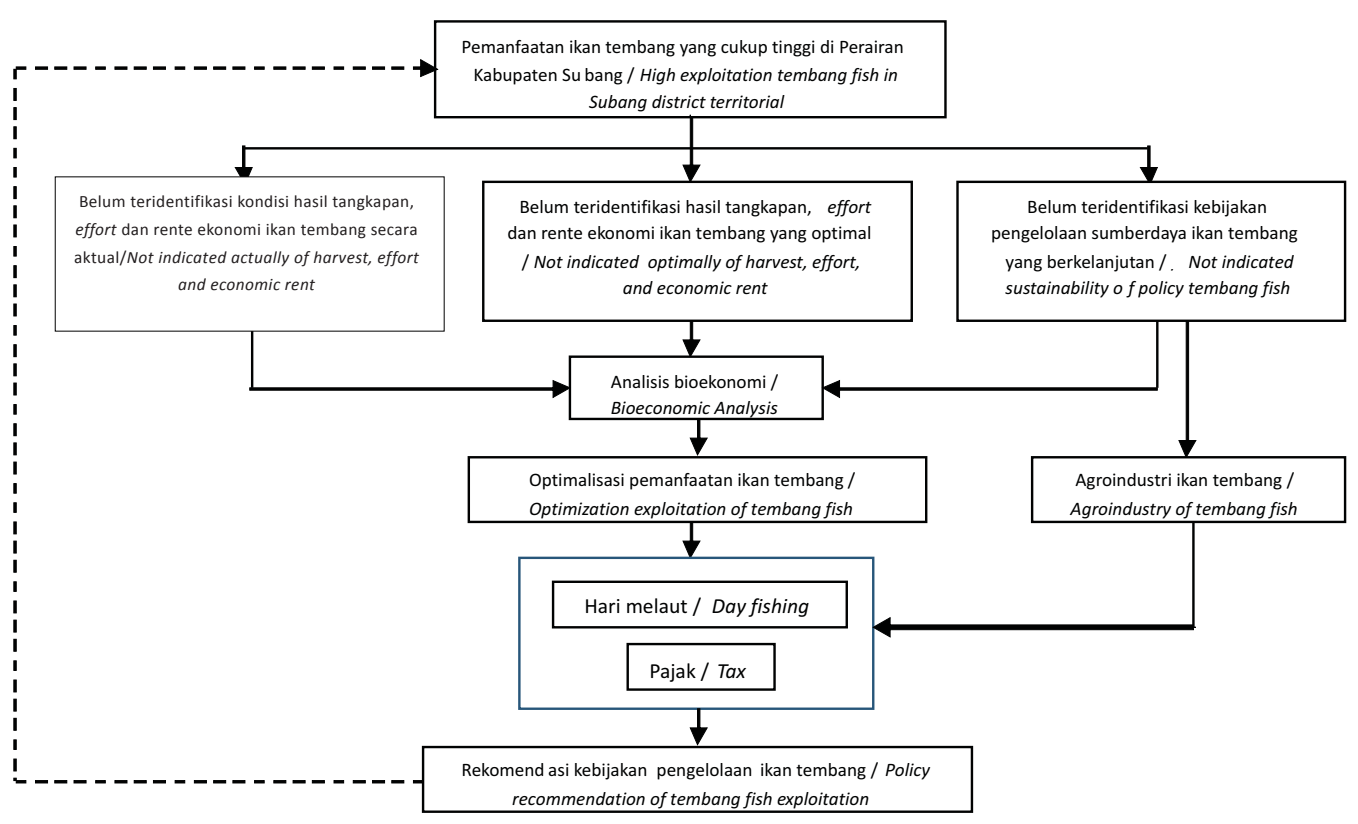

Gambar 1. Kerangka Pemikiran yang Digunakan dalam Penelitian. Figure 1. Research Framework Being Used in the Study.

\section{Jenis dan sumber data}

Pengumpulan data dilakukan melalui wawancara langsung dengan nelayan dan berpedoman pada daftar pertanyaan yang telah dibuat (kuesioner). Jenis data yang dikumpulkan dalam penelitian ini adalah data primer dan sekunder. Data primer terdiri dari biaya penangkapan, jenis alat tangkap yang digunakan, jumlah hari dalam setiap trip dan daerah penangkapan serta ukuran ikan tembang yang telah ditangkap. Data sekunder yang diperlukan adalah data berkala (time series) terdiri dari harga ikan, hasil tangkapan, upaya penangkapan selama sebelas tahun terakhir. Data ini diperoleh dari Biro Pusat Statistik Kabupaten Subang (BPS), Dinas Perikanan dan Kelautan (DKP) serta instansi-instansi yang terkait lainnya.

\section{Metode Pengumpulan Data}

Pengambilan sampel dilakukan dengan menggunakan metode purposive sampling atau pemilihan responden secara sengaja dengan pertimbangan bahwa responden dapat berkomunikasi dengan baik dalam pengisian kuesioner dan mengetahui cakupan pemanfaatan sumber daya ikan tembang. Responden dipilih merupakan nelayan yang mendaratkan hasil tangkapannya di TPI Desa Blanakan. Jumlah responden nelayan yang dalam penelitian ini sebanyak 30 menggunakan kapal dengan alat tangkap yang digunakan hanya ada satu yaitu purse seine dan menyebar normal di Kabupaten Subang. Hal ini berdasarkan jenis responden yang homogen dan asumsi dalam sampel ini adalah menyebar normal, sehingga jumlah sampel $\leq 30$ dapat dilakukan (Randika, 2008).

\section{Metode Analisis Data}

\section{Catch Per Unit Effort (CPUE)}

Setelah data produksi dan upaya (effort) disusun dalam bentuk time series selama sebelas tahun, maka dapat ditentukan nilai CPUE dengan merasiokan antara produksi dan effort. Menurut Gulland (1983) dalam Randika (2008), perhitungan CPUE bertujuan untuk mengetahui kelimpahan dan tingkat 
pemanfaatan sumberdaya perikanan pada suatu daerah perairan tertentu. Nilai CPUE dapat dinotasikan sebagai berikut:

$\mathrm{CPUE}_{\mathrm{t}}=\frac{\text { catch }_{t}}{\text { effort }_{t}}$

$\mathrm{t}=1,2, \ldots \mathrm{n}$

Di mana:

$\mathrm{CPUE}_{\mathrm{t}}=$ Tangkapan per upaya penangkapan pada tahun ke- t/ Catch Per Unit Effort at $t$ year (ton/trip)

Catch $_{\mathrm{t}}=$ Tangkapan pada tahun ke- $\mathrm{t} /$ Catch at $-t$ year (ton)

Effort $_{t}=$ Upaya penangkapan pada tahun ket/ Effort at -t year (trip)

Analisis bioekonomi menitikberatkan pada pendekatan biologi dan ekonomi yang merupakan salah satu alternatif upaya optimalisasi pengelolaan perikanan yang sustainable. Fungsi produksi lestari perikanan tangkap yang menggambarkan keterkaitan antara tingkat upaya penangkapan dan produksi lestari, menurut Schaefer (1957) dalam Fauzi (2004) adalah:

$\mathrm{h}=\mathrm{qke}-\left[\frac{\mathrm{q}^{2} \mathrm{~K}}{\mathrm{r}}\right] E^{2}$

dapat disederhanakan menjadi

$\mathrm{h}=\alpha E-\beta \mathrm{E}^{2}$, dimana $\alpha=\mathrm{q} K$ dan $\beta=\frac{K \mathrm{q}^{2}}{r}$

Keterangan:

$\mathrm{h}=$ Produksi tangkapan/ Harvest (ton)

$r=$ Laju pertumbuhan alami/ Rate fintrinsic growth (ton/tahun)

$\mathrm{K}=$ Kapasitas daya dukung lingkungan/ Carrying capacity (ton/tahun)

$\mathrm{q}=$ Koefisien kemampuan tangkap/ Catchability coefficient (ton/trip)

$\mathrm{E}=$ Upaya penangkapan/ Effort (trip)
Parameter fungsi produksi lestari ( $\alpha$ dan $\beta$ ) diestimasi melalui analisis regresi antara hasil tangkapan per unit tingkat upaya (h/E) pada berbagai tingkat upaya penangkapan dengan menggunakan model sebagai berikut:

$\mathrm{h} / \mathrm{E}=\alpha-\beta \mathrm{E}$

dimana :

\section{$\mathrm{CPUE}=\mathrm{h} / \mathrm{E}$}

Persamaan diatas secara umum dapat dituliskan sebagai:

$\mathrm{yi}=\beta 0+\beta 1 \mathrm{E}$

dengan membandingkan persamaan (4) dan (5) terlihat bahwa:

$\alpha=\beta_{0} \operatorname{dan} \beta=\beta_{1}$

Secara matematis, upaya penangkapan yang dilakukan untuk mencapai produksi maksimum lestari dapat ditulis menurut persamaan berikut:

$$
\begin{aligned}
& \frac{\partial h}{\partial E}=\alpha-2 \beta E=0 \\
& \mathrm{E}_{\mathrm{msy}}=\frac{\alpha}{2 \beta}
\end{aligned}
$$

Dari analisis regresi dengan menggunakan OLS pada persamaan (4), akan diperoleh nilai parameter alpha $(\alpha)$ dan beta $(\beta)$ yang disubstitusikan ke persamaan bentuk linear. Selain itu diperlukan parameter ekonomi, yaitu harga dan biaya. Dalam kajian bioekonomi, biaya penangkapan didasarkan atas asumsi bahwa hanya faktor penangkapan yang diperhitungkan, sehingga biaya penangkapan dapat didefinisikan sebagai 
variabel per trip operasi dan dianggap konstan.

Analisis bioekonomi pada penelitian ini menggunakan pendekatan optimal statik, di mana analisis tersebut tidak memasukkan faktor waktu. Sebagaimana yang telah dijelaskan sebelumnya bahwa model yang digunakan dalam penelitian ini adalah Gordon-Schaefer. Secara ringkas formulasi dari model tersebut dapat disajikan pada Tabel 1.

\section{HASIL DAN PEMBAHASAN}

\section{Keragaan Perikanan Tembang di Kabupaten Subang}

Pantai Kabupaten Subang terdapat di wilayah Pantura yang terdiri dari tiga kecamatan dan tujuh buah Pangkalan Pendaratan Ikan (PPI) dengan fasilitas yang terdiri dari Tempat Pelelangan Ikan (TPI), listrik, air tawar, dermaga, talud atau turap, BBM, pabrik es dan break water serta rumah nelayan. Setiap kecamatan memiliki TPI yang diunggulkan. Nama TPI yang diunggulkan dari masing-masing kecamatan adalah TPI Blanakan dari Kecamatan Blanakan yang dikelola oleh KUD Mina Fajar Sidik, TPI Mayangan dari Kecamatan Legonkulon yang dikelola oleh KUD Saluyu Mulya dan TPI Trungtum dari Kecamatan Pusakanagara yang dikelola oleh KUD Misaya Guna.
Dari tiga TPI tersebut yang menghasilkan ikan tembang terdapat pada TPI Blanakan Kecamatan Blanakan. Dua TPI dari kecamatan lainnya tidak terdapat hasil tangkapan ikan tembang. Hal ini dikarenakan pada daerah tersebut tidak ada jenis alat tangkap yang digunakan untuk menangkap ikan tembang selain purse seine. Purse seine merupakan alat tangkap yang digunakan untuk menangkap ikan gerombolan seperti ikan pelagis. Ukuran panjang dan kedalaman dari alat tangkap purse seine yang digunakan di TPI Blanakan masing-masing sekitar $200 \mathrm{~m}$ dan 30 $\mathrm{m}$. Alat tangkap tersebut dioperasikan dengan menggunakan alat bantu rumpon dari daun kelapa dan lampu.

Armada yang digunakan nelayan purse seine adalah jenis kapal motor dengan ukuran berkisar antara 13 sampai 29 GT. Setiap kapal mempunyai jumlah nelayan sekitar 21 sampai 25 orang yang terdiri dari nakhoda, juru masak, penyelam, penjaga mesin dan sebagainya sesuai dengan tugas masing-masing anak buah kapal (ABK). Jika bulan gelap, maka penangkapan ikan dilakukan pada malam hari yang biasa terjadi pada tanggal 19 sampai 30 dan 1 sampai 5 di bulan Hijriyah. Sebaliknya, jika terang bulan, maka penangkapan dilakukan pada siang hari yang biasa terjadi pada tanggal 10 sampai 15 di bulan Hijriyah. Pada malam hari nelayan menggunakan alat bantu lampu, sedangkan pada siang hari menggunakan alat bantu rumpon.

Tabel 1. Formula Model Gordon-Schaefer.

Table 1. Gordon Schaefer Model Formula.

\begin{tabular}{cccc}
\hline \multirow{2}{*}{ Variabel/Variable } & \multicolumn{2}{c}{ Rezim Pengelolaan } & \multicolumn{2}{c}{ Regime Management } \\
\cline { 2 - 4 } & MEY & MSY & Open Access \\
\hline $\begin{array}{c}\text { Upaya Penangkapan } \\
\text { / Effort (E) }\end{array}$ & $\frac{p \alpha-c}{2 \beta p}$ & $\frac{\alpha}{2 \beta}$ & $\frac{p \alpha-c}{p \beta}$ \\
$\begin{array}{c}\text { Produksi tangkapan / } \\
\text { Catch Production } \\
\begin{array}{c}\text { Rente ekonomi / } \\
\text { Economic rent }(\pi)\end{array}\end{array}$ & $\alpha\left(\mathrm{E}_{\mathrm{MEY}}\right)-\beta\left(\mathrm{E}_{\mathrm{MEY}}\right)^{2}$ & $\frac{\alpha^{2}}{4 \beta}$ & $\alpha\left(\mathrm{E}_{\mathrm{OA}}\right)-\beta\left(\mathrm{EOA}^{2}\right)^{2}$ \\
\hline
\end{tabular}

Sumber : Diacu dalam Fauzi (2005) / Source: Reffer to Fauzi (2005) 
Jika nelayan menggunakan alat bantu rumpon, maka nelayan dapat beroperasi pada selain tanggal yang telah disebutkan sebelumnya.

Penangkapan ikan dilakukan di daerah pantai yang berjarak sekitar 50 sampai 90 mil ke arah utara dari pantai Blanakan. Setiap bulannya nelayan purse seine selalu menghasilkan tangkapan ikan tembang. Namun, puncak tangkapan hasil ikan tembang yang tinggi terjadi pada kisaran bulan Juni sampai Oktober dan terjadinya hasil yang rendah pada kisaran bulan Desember sampai Februari. Pembagian hasil tangkapan dilakukan setelah melakukan pelelangan dan membeli kebutuhan yang diperlukan untuk pengoperasian berikutnya. Dalam hal ini pihak KUD mendapat bagian 5\% dari hasil tangkapan nelayan. Sedangkan untuk anak buah kapal (ABK) dan pemilik masingmasing mendapat $50 \%$ dari hasil tangkapan setelah dikurangi biaya.

\section{Analisis Bioekonomi}

Pada Tabel 2 terlihat bahwa perkembangan produksi ikan tembang dari setiap tahunnya mengalami peningkatan dengan rata-rata produksi dari periode 1998-
2008 adalah 1.492 ton. Jumlah produksi tertinggi dan terendah dicapai pada tahun 2002 sebesar $2.064,5$ ton dan 2005 sebesar 775,8 ton. Sedangkan peningkatan dan penurunan yang paling drastis terjadi pada tahun 2006 sebesar $80,63 \%$ dan 2005 sebesar $42,77 \%$.

Penurunan produksi ikan tembang pada tahun 2005 dikarenakan adanya pengurangan pengoperasian (effort) penangkapan ikan. Hal ini lebih disebabkan oleh peningkatan pada harga bahan bakar minyak (BBM) tahun tersebut sehingga mengakibatkan peningkatan biaya operasional yang lebih tinggi dibandingkan dengan penerimaannya.

Berdasarkan Tabel 2 terlihat bahwa rata-rata CPUE ikan tembang dari periode 1998-2008 sebesar 0,799 yang berarti bahwa dengan tingkat effort sebesar 2.912 trip akan menghasilkan produksi sebesar 1.491,97 ton. Selanjutnya untuk memperoleh nilai $\alpha$ dan $\beta$ maka dilakukan pengolahan data dengan OLS dari Tabel 2, dimana CPUE sebagai variabel y dan effort sebagai variabel $x$. Hasil pengolahan data menggunakan OLS tersebut dapat dilhat pada Tabel 3.

Tabel 2. Produksi, Effort dan CPUE Ikan Tembang di Kabupaten Subang, 1998-2008. Table 2. Production, Effort and CPUE of Tembang Fish in Subang Regency, 1998-2008.

\begin{tabular}{cccc}
\hline Tahun/ Years & $\begin{array}{c}\text { Produksi Tangkapan/ } \\
\text { Catch Production (ton) }\end{array}$ & Effort (trip) & CPUE (ton per trip) \\
\hline 1998 & $1,291.20$ & 4,320 & 0.299 \\
1999 & $1,110.20$ & 4,320 & 0.257 \\
2000 & $1,475.60$ & 4,608 & 0.320 \\
2001 & $2,049.60$ & 4,800 & 0.427 \\
2002 & $2,064.50$ & 2,813 & 0.734 \\
2003 & $1,943.50$ & 2,907 & 0.669 \\
2004 & $1,355.50$ & 4,600 & 0.295 \\
2005 & 775.80 & 1,078 & 0.720 \\
2006 & $1,401.30$ & 766 & 1,830 \\
2007 & $1,337.50$ & 907 & 1,475 \\
2008 & $1,607.00$ & 909 & 1,768 \\
\hline Rata-rata/ & $1,491.97$ & $\mathbf{2 , 9 1 2}$ & $\mathbf{0 . 7 9 9}$ \\
Average & & & \\
\hline
\end{tabular}

Sumber : Data diolah, 2010 / Source: Processed data, 2010

Keterangan : Alat tangkap digunakan yaitu purse seine / Description: Fishing gear used is Purse seine 
Tabel 3. Nilai Parameter $\alpha$ dan $\beta$ dari Hasil Pengolahan Menggunakan OLS. Tabel 3. Parameter Values $\alpha$ and $\beta$ of Processing Results Using a OLS.

\begin{tabular}{cc} 
Parameter & Hasil/Result \\
\hline$\alpha$ & 1.71324 \\
$\beta$ & -0.00031 \\
$\mathrm{R}^{2}$ & 0.790035 \\
\hline
\end{tabular}

Sumber : Hasil olahan, 2010 / Source : Processed data, 2010

Hasil pengolahan data menghasilkan nilai $\mathrm{R}^{2}$ yang cukup tinggi yaitu sebesar $79 \%$. Selain itu, hasil olahan menunjukkan korelasi antara CPUE dan effort adalah negatif. Hubungan tersebut dinyatakan dalam persamaan $\mathrm{Y}=1,71324-0,00031 \mathrm{E}$, dimana $\mathrm{Y}=\mathrm{CPUE}$, koefisien $\alpha=1,71324$ dan $\beta=-0,00031$. Persamaan ini berarti bahwa setiap terjadi peningkatan effort (E) sebesar satu-satuan (trip), maka akan menurunkan jumlah CPUE (Y) sebesar 0,00031 ton per trip. Hal ini dibuktikan dengan data dalam Tabel 2 bahwa jika tingkat effort di atas angka seribu, maka akan menghasilkan nilai CPUE di bawah angka satu, sedangkan jika tingkat effort di bawah angka seribu, maka menghasilkan nilai CPUE di atas angka satu.
Gambar 2 menunjukkan pertumbuhan produksi lestari cenderung mengalami peningkatan rata-rata sebesar $5,96 \%$. Produksi lestari yang sangat rendah terjadi pada tahun 2001 karena tingkat effort pada tahun tersebut sangat tinggi sebesar 4.800 trip yang telah melebihi effort maksimum (2.729 trip). Sedangkan produksi yang sangat tinggi terjadi pada tahun 2002 dengan effort sebesar 2.813 trip. Namun, jumlah produksi tersebut masih di bawah tingkat maksimum (MSY) dengan tingkat effort yang melebihi jumlah maksimum. Jumlah produksi lestari akan terus meningkat seiring dengan peningkatan effort sampai mencapai tingkat maksimum. Akan tetapi pada saat effort melebihi tingkat maksimum akan menurunkan produksi lestari seiring dengan peningkatan pada jumlah effort.

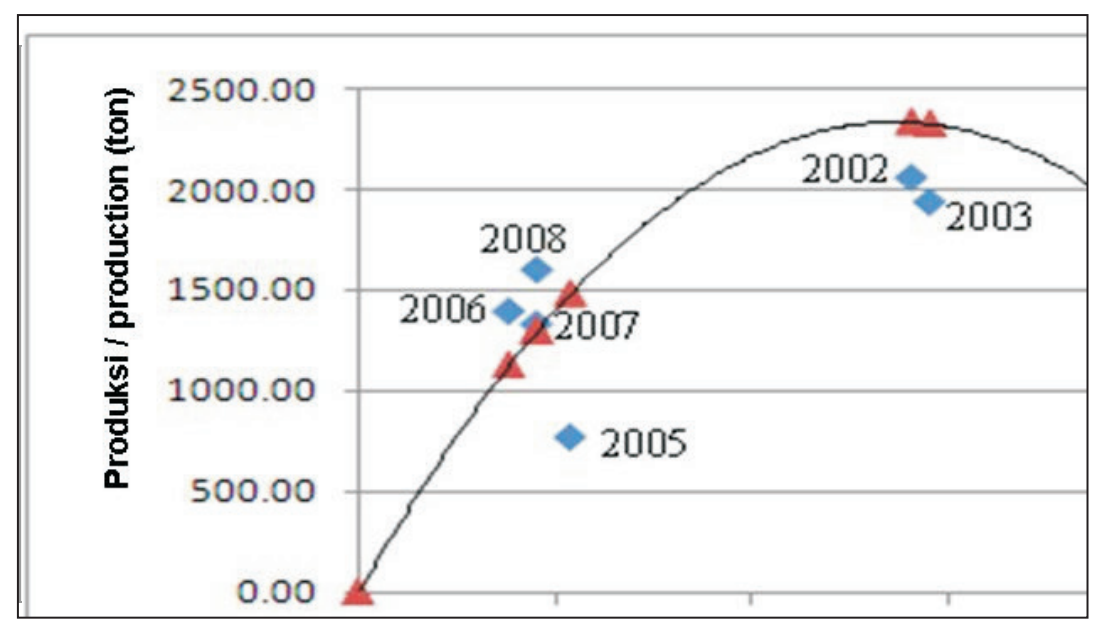

Gambar 2. Perbandingan Produksi Aktual dan Lestari Ikan Tembang di Kabupaten Subang, 1998-2008.

Figure 2. Compare of Actual and Sustainable Production Tembang Fish in Subang Regency, 1998-2008. 


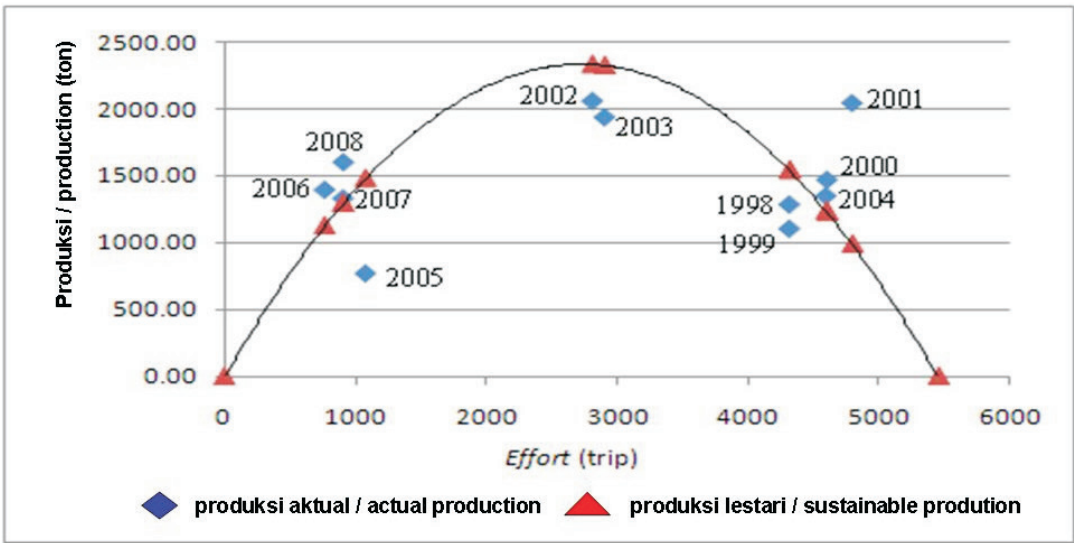

\section{Gambar 3. Kurva Kuadratik Produksi Aktual dan Lestari Ikan Tembang di Kabupaten Subang pada 1998-2008.}

Figure 3. Quadratic Curve Actual and Sustainable Production of Tembang Fish in Subang Regency at 1998-2008.

Dari Gambar 3 nampak bahwa produksi aktual yang melebihi produksi lestari terjadi pada tahun 2000-2001, 2004 dan 2006-2008, sedangkan produksi aktual yang masih di bawah produksi lestari terjadi pada tahun 1998-1999, 2002-2003, dan 2005. Produksi aktual yang telah melebihi lestarinya mengindikasikan bahwa tahun tersebut telah mengalami overfishing. Sebaliknya, produksi aktual yang masih di bawah lestarinya mengindikasikan bahwa tahun tersebut belum mengalami overfishing.

Model yang digunakan pada penelitian ini adalah model Gordon Schaefer. Penggunaan model ini dikarenakan adanya kesesuaian dengan asumsi yang berlaku pada model tersebut. Selain itu nilai $\mathrm{R}^{2}$ dari model Gordon Schaefer hampir mendekati satu, yaitu 0,79. Nilai $R^{2}$ menunjukkan tingkat persentase dari keragaman variabel $Y$ yang menggambarkan hubungan linear dengan variabel $X$. Semakin tinggi nilai $R^{2}$ mendekati angka 1 atau 100\% menunjukkan bahwa model semakin baik. Dengan demikian model Gordon Schaefer tepat untuk digunakan dalam penelitian ini karena nilai $R^{2}$ yang dihasilkan mendekati angka satu.
Data yang digunakan untuk melakukan regresi dapat dilihat pada Tabel 2. Nilai $R$ sebesar 0,89 menunjukkan adanya korelasi yang tinggi antara peubah bebas (E) dan tidak bebas (CPUE). Sedangkan nilai R2 yang bernilai 0,79 menunjukkan bahwa 79\% keragaman nilai CPUE dipengaruhi oleh variabel bebas (E) dan sisanya dipengaruhi variabel lain diluar model. Model Ordinary Least Square (OLS) untuk sumber daya ikan tembang adalah $Y=1,71324-0,00031 \mathrm{E}$.

di mana,

$\mathrm{Y}=$ CPUE (produksi per unit upaya) / Catch Per Unit Effort

$\mathrm{E}=$ Upaya penangkapan/ Effort

Parameter alpha dan beta digunakan dalam menentukan tingkat produksi pada pengelolaan MSY, MEY dan open access. Biaya penangkapan per trip terdiri dari biaya tetap dan biaya variabel. Biaya tetap meliputi harga perahu, mesin, alat tangkap, perawatan perahu, perawatan mesin dan perawatan alat tangkap. Sedangkan pada biaya variabel terdiri dari biaya BBM, es balok, oli, pangan, perizinan berlayar dan rumpon.

Biaya penangkapan dihasilkan dari perhitungan rata-rata biaya variabel dari 
sampel nelayan purse seine yang menangkap ikan tembang. Dengan demikian diperoleh total biaya yang dikeluarkan sebesar Rp 1.690.217 per trip. Rincian biaya operasional penangkapan ikan disajikan pada data dalam Tabel 4.

Salah satu aspek ekonomi yang diperlukan dalam kajian bioekonomi adalah faktor harga. Harga ikan diperoleh dari rata-rata data sekunder harga ikan di Dinas Kelautan dan Perikanan (DKP) Kabupaten Subang yang telah disesuaikan dengan Indeks Harga Konsumen (IHK) guna mengeliminir pengaruh inflasi (Nababan, 2006). Berdasarkan perhitungan tersebut, maka diperoleh nilai harga rata-rata sebesar $\mathrm{Rp} 3.344,624$ per $\mathrm{kg}$ yang dapat dilihat pada data dalam Tabel 5.

Jika dikonversi ke dalam satuan ton, maka menjadi Rp 3.344.624 per ton. Dari data tersebut terlihat bahwa ikan tembang memiliki nilai jual yang cukup rendah.

Tabel 4. Biaya Operasional Penangkapan Ikan Tembang di Kabupaten Subang, 2010.

Table 4. Operational Cost for Tembang Fish Capture in Subang Regency, 2010.

\begin{tabular}{clc} 
No & \multicolumn{1}{c}{$\begin{array}{c}\text { Biaya Operasional/ } \\
\text { Operational cost }\end{array}$} & $\begin{array}{c}\text { Rata-rata Biaya Per Kapal Purse Seine/ } \\
\text { Average cost per vessel purse seine (Rp) }\end{array}$ \\
\hline 1 & BBM / Fuel & $2,300,000$ \\
2 & Es balok / Block Ice & 705,166 \\
3 & Oli / Oil & 121,833 \\
4 & Perbekalan melaut / Ransoom & $1,883,333$ \\
5 & Perizinan berlayar / Licence & 21,000 \\
6 & Rumpon / Rumpoon & $1,525,000$ \\
\hline Total biaya operasional per kapal / & $6,556,333$ \\
Total operational cost per vessel & \\
\hline Biaya operasional komposisi ikan tembang \\
per kapal / Operational cost tembang fish \\
composition per vessel (26\%)
\end{tabular}

Sumber : Hasil analisis data (2010) / Source: Data analyzed (2010)

Tabel 5. Harga Nominal dan Harga Riil Ikan Tembang serta IHK Perikanan di Kabupaten Subang, 2010.

Table 5. Nominal and Real Price of Tembang Fish and CPI of Fisheries in Subang Regency, 2010.

\begin{tabular}{cccc}
\hline Tahun / Years & $\begin{array}{c}\text { Harga Nominal } \\
\text { / Nominal Price }\end{array}$ & $\begin{array}{c}\text { IHK Kabupaten Subang / } \\
\text { CPI Subang Regent (Tahun } \\
\text { Dasar / base year= 2005) }\end{array}$ & $\begin{array}{c}\text { Harga Riil / Real Price } \\
\text { (Rp/Kg) }\end{array}$ \\
\hline 2002 & 4,400 & 1,0278 & $4,281,001$ \\
2003 & 2,000 & 1,1030 & $1,813,278$ \\
2004 & 3,000 & 0.9995 & $3,001,434$ \\
2005 & 4,000 & 1,0000 & $4,000,000$ \\
2006 & 4,000 & 1,0040 & $3,984,018$ \\
2007 & 3,000 & 1,0040 & $2,988,014$ \\
\hline Rata rata / Average & & & $\mathbf{3 , 3 4 4 , 6 2 4}$ \\
\hline
\end{tabular}

Sumber : Data diolah, 2010 / Source: Data processed, 2010 
Analisis bioekonomi yang digunakan dalam penelitian ini adalah model Gordon Schaefer. Model ini menghasilkan parameter alpha dan beta yang telah diperoleh pada keterangan sebelumnya. Parameter ekonomi yang digunakan adalah biaya penangkapan per trip dan harga ikan tembang per kg yang dikonversi dalam ton. Hasil dari parameterparameter tersebut dapat dilihat pada data dalam Tabel 6. yang berkaitan dengan tingkat upaya yang diperbolehkan untuk pengelolaan yang sustainable. Nilai effort dari rezim pengelolaan MSY sebesar 2.729 trip per tahun, MEY sebesar 1.924 trip per tahun dan OA sebesar 3.848 trip per tahun.

Nilai rente ekonomi menunjukkan tingkat keuntungan secara ekonomi dalam upaya pemanfaatan sumber daya ikan tembang. Nilai ini menyimpan informasi mengenai

Tabel 6. Parameter Alpha, Beta dan Ekonomi Perikanan Tembang di Kabupaten Subang, 2010. Table 6. Alpha, Beta and Economic Parameters of Tembang Fisheries in Subang Regency, 2010.

\begin{tabular}{cc} 
Parameter & Nilai / Value \\
\hline Alpha & 1.71324 \\
Beta & -0.00031 \\
Biaya / Cost (Rp per trip) & $1,690,217$ \\
Harga / Price (Rp per ton) & $3,344,624$ \\
\hline
\end{tabular}

Sumber : Hasil analisis data, 2010 / Source : Data analysed, 2010

\section{Analisis Optimalisasi Sumber Daya Ikan Tembang}

Parameter yang telah dihasilkan dapat digunakan untuk mencari produksi dari berbagai rezim pengelolaan, yaitu MSY, MEY dan open access. Hasil perhitungan produksi tersebut dapat dilihat pada Tabel 7. Nilai produksi menunjukkan hasil tangkapan dari upaya pemanfaatan sumber daya ikan tembang. Nilai ini menyimpan informasi besarnya hasil tangkapan yang diperbolehkan untuk pengelolaan yang berkelanjutan. Tingkat produksi pada rezim pengelolaan MSY sebesar 2.337,62 ton per tahun, MEY sebesar 2.134,24 ton per tahun dan OA sebesar 1.944,55 ton per tahun.

Nilai effort menunjukkan tingkat upaya yang dilakukan dalam pemanfaatan sumber daya ikan tembang di Kabupaten Subang. Nilai ini menyimpan informasi

Tabel 7. Hasil Analisis Bioekonomi Perikanan Tembang di Kabupaten Subang, 2010.

Table 7. Result of Tembang Fisheries Bioeconomic Analysis in Subang Regency, 2010.

\begin{tabular}{lccc}
\hline \multirow{2}{*}{$\begin{array}{c}\text { Rezim pengelolaan / } \\
\text { Management Regime }\end{array}$} & $\begin{array}{c}\text { Parameter } \\
\text { Production (ton) }\end{array}$ & Effort (trip) & $\begin{array}{c}\text { Rente Ekonomi / } \\
\text { Economic Rent (Rp) }\end{array}$ \\
\cline { 2 - 4 } Aktual / Actual & $1,491.97$ & 2,912 & $68,790,706$ \\
MSY & $2,337.62$ & 2,729 & $3,206,066,795$ \\
MEY & $2,134.24$ & 1,924 & $3,886,324,795$ \\
OA & $1,944.55$ & 3,848 & 0 \\
\hline
\end{tabular}

Sumber : Hasil analisis, 2010 / Source : Data analyzed, 2010 
besarnya tingkat keuntungan untuk pengelolaan yang sustainable. Tingkat rente ekonomi pada kondisi MSY sebesar Rp 3.206.066.795, MEY sebesar Rp 3.886.324.795 dan OA sebesar Rp 0.

Rata-rata jumlah produksi, effort dan rente ekonomi pada kondisi aktual masingmasing sebesar 1.491,97 ton per tahun, 2.912 trip per tahun dan Rp.68.790.706. Ratarata tingkat produksi aktual ikan tembang lebih rendah dibandingkan dengan tingkat produksi dari berbagai rezim pengelolaan (MSY, MEY dan OA). Hal ini menunjukkan bahwa pemanfaatan sumber daya ikan tembang belum mengalami overfishing secara biologi. Sedangkan pada tingkat effort aktual berjumlah lebih besar dibandingkan dengan jumlah effort dari dua rezim pengelolaan, yaitu MSY dan MEY, tetapi lebih kecil jika dibandingkan dengan rezim pengelolaan OA. Kondisi ini menunjukkan bahwa pemanfaatan sumberdaya ikan tembang telah mengalami overcapacity. Hal ini dikarenakan ikan tembang memiliki nilai jual yang cukup rendah sehingga nelayan lebih memilih tangkapan ikan yang mempunyai nilai jual tinggi. Dampaknya adalah ikan tembang yang telah di tangkap akan terbuang ketika nelayan memperoleh penangkapan ikan bernilai jual tinggi (by catch) dan pada akhirnya penangkapan ikan tersebut tidak terdata dalam laporan.

Jumlah effort aktual yang melebihi kondisi MSY dan MEY menyebabkan tingginya biaya yang digunakan dalam penangkapan ikan tembang, sedangkan harga ikan tembang bernilai rendah. Kondisi ini akan berimplikasi pada nilai rente ekonomi yang rendah. Berdasarkan keterangan di atas, terlihat bahwa pengelolaan penangkapan ikan tembang di Perairan Kabupaten Subang belum optimal atau menyamai pengelolaan pada kondisi OA, di mana pada perolehan nilai rente ekonomi yang rendah nelayan masih mengoperasikan effort dalam jumlah yang tinggi untuk mencari ikan, sehingga berdampak pada minimnya manfaat ekonomi yang diperoleh nelayan. Oleh karena itu, dibutuhkan intervensi dari pemerintah Kabupaten Subang untuk mengatasi permasalahan pengelolaan penangkapan ikan tembang di Perairan Kabupaten Subang. Sehubungan dengan hal ini, maka dapat dilakukan dengan beberapa instrumen kebijakan dalam perikanan.

\section{Analisis Pengelolaan Ikan Tembang Menggunakan Instrumen Pajak}

Berdasarkan hasil yang diperoleh dari perhitungan model Gordon-Schaefer menunjukkan terjadinya overcapacity, artinya effort pada kondisi aktual telah melebihi jumlah effort pada pengelolaan MSY dan MEY. Kebijakan untuk mengendalikan pemanfaatan sumber daya ikan tembang dari aspek input produksi adalah menjaga upaya penangkapan ikan tembang pada level optimal, yaitu sebesar 1.924 trip. Dengan demikian pemerintah Kabupaten Subang diharapkan dapat menetapkan dan tidak menambah tingkat upaya dalam penangkapan ikan tembang. Hal ini untuk mencegah ketidakoptimalan dalam pemanfaatan sumber daya ikan tembang yang mengakibatkan terjadinya penurunan produktivitas dan pendapatan yang diterima nelayan.

Oleh karena itu, dibutuhkan suatu regulasi untuk mengatasi terjadinya penggunaan effort yang berlebih dari tingkat optimal, salah satu instrumen yang dapat mengurangi tingkat effort adalah pajak (Fauzi, 2010). Penerapan instrumen ini dapat dilakukan melalui penggunaan input dan output.

Nababan (2006), menyatakan pajak terhadap input merupakan salah satu instrumen yang dapat mengurangi jumlah effort yang telah melebihi tingkat optimal. Pajak ini diberlakukan pada setiap trip dan mempengaruhi biaya total operasional. Secara matematis dapat diformulasikan : $\mathrm{TC}=\mathrm{cE}$ dan $\mathrm{TC}_{\mathrm{r}}=\left(\mathrm{C}_{\mathrm{r}}+\left({ }^{*} \mathrm{c}\right)\right) \mathrm{E}$

Tingkat effort OA sebelum diterapkan pajak sebesar 3.848 trip dan setelah dikenakan pajak input tingkat effort akan berkurang sesuai dengan besarnya pajak, artinya semakin tinggi nilai pajak akan semakin tinggi pengurangan terhadap 
tingkat effort. Pada data dalam Tabel 8 terlihat bahwa besar pajak yang dapat mengurangi effort sampai tingkat MEY adalah 119,51\%. penjadwalan hari melaut bagi nelayan purse seine yang dikombinasikan dengan alternatif pekerjaan lain berupa agro industri yang terkait erat dengan ikan tembang.

Tabel 8. Dampak Pajak Input terhadap Effort Perikanan Tembang di Kabupaten Subang, 2010. Table 8. Impact of Input Tax on Fishing Effort Tembang in Subang Regency, 2010.

\begin{tabular}{cccc}
$\begin{array}{c}\text { Pajak Input / Tax } \\
\text { Input (\%) }\end{array}$ & $\begin{array}{c}\text { Effort Before Tax } \\
\text { (Trip) }\end{array}$ & $\begin{array}{c}\text { Effort After Tax } / \tau_{\text {in }} \\
\text { (Trip) }\end{array}$ & $\Delta \mathrm{E}(\%)$ \\
\hline 15.00 & 3,848 & 3,606 & -6.29 \\
30.00 & 3,848 & 3,364 & -12.58 \\
45.00 & 3,848 & 3,123 & -18.84 \\
54.44 & 3,848 & 2,971 & -22.79 \\
60.00 & 3,848 & 2,882 & -25.10 \\
& & & -50.00 \\
\hline
\end{tabular}

Sumber : Hasil analisis, 2010 / Source : Data analyzed, 2010

Untuk mengurangi effort yang berlebih selain pajak input, pemerintah juga dapat menerapkan pajak output. Pajak ini diberlakukan pada setiap output atau setiap unit ikan yang dijual. Pajak output akan mempengaruhi penerimaan nelayan penangkap ikan tembang. Secara matematis dapat diformulasikan sebagai berikut: penerimaan sebelum pajak yaitu $T R=p h$, penerimaan setelah pajak yaitu $\operatorname{TR}_{\mathrm{r}}=\left(p-\left(r^{*} p\right)\right) h$.

Sebelum diterapkan pajak output, tingkat effort OA sebesar 3.848 trip dan setelah diterapkan pajak tingkat effort akan berkurang sesuai dengan banyaknya pajak yang diterapkan. Dari data dalam Tabel 9 terlihat bahwa jumlah pajak yang dapat mengurangi effort sampai pada tingkat optimal (MEY) sebesar $54,44 \%$. Hal ini menunjukkan pengaruh pajak output lebih tinggi dibandingkan dengan pajak input. Namun, pajak output ataupun input tidak dapat diterapkan oleh pemerintah karena nilai tersebut terlalu tinggi bagi nelayan penangkap ikan tembang sehingga diperlukan alternatif kebijakan lain yang lebih aplikatif, yaitu menetapkan tingkat effort optimal yang dapat dilakukan dengan

Tabel 9. Dampak Pajak Output terhadap Effort Perikanan Tembang di Kabupaten Subang, 2010.

Table 9. Impact of Output Tax on Fishing Effort Tembang in Subang Regency, 2010.

\begin{tabular}{cccc}
\hline $\begin{array}{c}\text { Pajak Output / Tax } \\
\text { Output (\%) }\end{array}$ & $\begin{array}{c}\text { Effort before tax } \\
\text { (trip) }\end{array}$ & $\begin{array}{c}\text { Effort after tax } / \tau_{\text {out }} \\
\text { (trip) }\end{array}$ & $\Delta \mathrm{E}(\%)$ \\
\hline 15.00 & 3,848 & 3,564 & -7.38 \\
30.00 & 3,848 & 3,158 & -17.93 \\
45.00 & 3,848 & 2,531 & -34.23 \\
54.44 & 3,848 & 1,924 & -50.00 \\
60.00 & 3,848 & 1,433 & -62.76 \\
\hline
\end{tabular}

Sumber : Hasil analisis, 2010 / Source: Data analyzed, 2010 
Armada yang tidak melaut dapat giliran istirahat 1 hari dan bekerja pada pengembangan agroindustri 2 hari. Setiap istrrahat dilakukan oleh 5 armada dan armada yang bekerja pada agroindustri setiap harinya sebanyak 10 armada

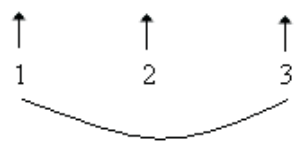

Tahap 1 (15 armada) melaut, tahap 2 (15 armada lainnya) tidak melaut

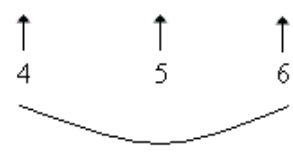

Tahap 2 melaut, tahap 1 tidak melaut

Gambar 4. Ilustrasi Pengaturan Jadwal Melaut yang Dikombinasikan dengan Agroindustri Perikanan Tembang di Kabupaten Subang, 2010.

Figure 4. Illustration Schedulle for Fishing Combined with Agroindustry of Tembang Fisheries in Subang Regency, 2010.

\section{Pengaturan Jadwal Hari Melaut}

Pada Gambar 4 menunjukkan ilustrasi pengaturan jadwal melaut yang dikombinasikan dengan agroindustri. Pengaturan penjadwalan hari melaut dapat disimulasikan sebagai berikut:

1. Upaya optimal atau MEY sebanyak 1.924 trip per tahun (hasil analisis), jumlah hari dari setiap trip adalah tiga hari (hasil wawancara dengan nelayan) dan armada sebanyak 30 unit (sampel yang diambil dalam penelitian) sehingga upaya optimum per bulan per armada adalah 5 trip.

2. Pergiliran melaut dilakukan sebanyak dua tahap. Tahap pertama diterapkan pada 15 armada dan tahap kedua diterapkan pada 15 armada lainnya. Tahap ini dilakukan secara bergiliran dengan selang waktu selama tiga hari, artinya jika armada tahap pertama melakukan operasi penangkapan, maka armada pada tahap kedua mendapat giliran istirahat yang dikombinasikan dengan alternatif pekerjaan baru berupa agroindustri selama operasi penangkapan yang dilakukan armada tahap pertama (tiga hari). Sebaliknya, jika armada tahap kedua yang melakukan operasi penangkapan, maka armada tahap pertama mendapat giliran istirahat.

3. Istirahat dilakukan selama satu hari dan alternatif pekerjaan baru (agroindustri) dilakukan selama dua hari. Pengkombinasian istirahat dan alternatif pekerjaan baru dilakukan secara bergiliran pada setiap lima armada yang tidak mendapat giliran melaut.

Sebagai catatan untuk nelayan yang melakukan alternatif pekerjaan baru (agroindustri), saat mendapat giliran tidak melaut adalah nelayan yang tidak memiliki pekerjaan sampingan atau utama.

\section{KESIMPULAN DAN IMPLIKASI KEBIJAKAN}

\section{Kesimpulan}

1. Kondisi tangkapan ikan tembang di Perairan Kabupaten Subang secara aktual telah mengalami overcapacity, karena tingkat effort aktual telah melebihi jumlah effort pada pengelolaan MSY dan MEY. Akan tetapi belum overfishing secara biologi, karena murahnya harga ikan tembang yang menyebabkan nelayan lebih tertarik untuk mencari ikan yang mempunyai nilai jual tinggi, sehingga terbuangnya ikan tembang yang telah ditangkap ketika nelayan mendapat ikan bernilai jual tinggi. 
2. Pada pengelolaan MSY jumlah tangkapan adalah sebesar $2.337,62$ ton per tahun, effort sebesar 2.729 trip per tahun dan rente ekonomi sebesar Rp 3.206.066.795 per tahun. Sedangkan pada pengelolaan MEY jumlah tangkapan adalah sebesar 2.134,24 ton per tahun, effort sebesar 1.924 trip per tahun dan rente ekonomi sebesar Rp 3.886.324.795 per tahun.

3. Regulasi yang digunakan dalam penelitian ini adalah pajak. Regulasi ini tidak dapat diterapkan kepada nelayan karena nilainya terlalu tinggi, yaitu sebesar $54,44 \%$ pada pajak output dan $119,51 \%$ pada pajak input. Namun, regulasi ini dapat diterapkan ketika terjadi dampak negatif dari kebijakan alternatif berupa penjadwalan hari melaut yang dikombinasikan dengan agroindustri.

\section{Implikasi Kebijakan}

1. Melakukan pendataan yang lebih baik dalam pemanfaatan sumber daya ikan untuk menunjang pembuatan kebijakan yang lebih tepat.

2. Rekomendasi kebijakan alternatif yang dapat dilakukan adalah pengaturan jadwal hari melaut yang dikombinasikan dengan pengembangan agroindustri tepung ikan seperti yang diterangkan dalam penjelasan sebelumnya.

3. Regulasi atau kebijakan dalam sumberdaya perikanan tidak dapat berdiri sendiri mengingat sumber daya perikanan yang open akses. Oleh karena itu regulasi yang diberikan haruslah seiring dengan kebijakan atau regulasi lain agar tetap menjaga keberlanjutan sumber daya perikanan dan tetap memberikan dampak ekonomi bagi kesejahteraan masyarakat Dalam penelitian ini kebijakan yang digunakan bagi perikanan tangkap tembang di Kabupaten Subang yaitu simulasi kebijakan pajak input dan output, kebijakan penjadwalan hari melaut dan kebijakan agroindustri perikanan tembang.

\section{DAFTAR PUSTAKA}

Biro Pusat Statistik Kabupaten Subang. 2008. Subang dalam Angka Tahun 2008. BPS. Subang.

Dinas Kelautan dan Perikanan Kabupaten Subang. 2008. Evaluasi Program Pembangunan Kelautan dan Perikanan Kabupaten Subang Tahun 2008. DKP. Subang.

Dinas Kelautan dan Perikanan Kabupaten Subang. 2008. Statistik Penangkapan Laut 2008. DKP. Subang.

Fauzi, A dan Suzy A. 2005. Pemodelan Sumberdaya Perikanan dan Kelautan untuk Analisis Kebijakan. Gramedia Pustaka Utama. Jakarta.

Fauzi, A. 2004. Ekonomi Sumberdaya Alam dan Lingkungan. Gramedia Pustaka Utama. Jakarta.

Fauzi, A. 2010. Ekonomi Perikanan:Teori, Kebijakan dan Pengelolaan. Gramedia Pustaka Utama. Jakarta.

Nababan, B.O. 2006. Analisis Dampak Perdagangan Sumberdaya LRFF terhadap Sumberdaya Perikanan (Studi Kasus di Perairan Kepulauan Spermonde, Sulawesi Selatan). Thesis. IPB.

Randika, Z. A. 2008. Analisis Bioekonomi Pemanfaatan Optimal Sumberdaya Perikanan Pelagis dan Demersal di Perairan Balikpapan, Kalimantan Timur. Tesis. Sekolah Pascasarjana. Institut Pertanian Bogor. Bogor. 